\title{
KONSEP DIRI DALAM KOMUNIKASI
}

\author{
Ibrahim
}

\begin{abstract}
Abstrak
Konsep Dirimerupakan unsur penting dalam setiap komunikasi. Pemahaman yang baik terhadap diri dan orang lain akan sangat menentukan keberhasilan sebuah komunikasi. Karena itu, artikel ini memberikan fokus kajian pada aspek konsep diri dalam komunikasi antarbudaya pada mahasiswa KPI angkatan 2011/2012. Hasil kajian inimendapati bahwa konsep diri menjadi faktor utama dalam menentukan keberhasilan komunikasi antarbudayadalam diri mahasiswa, dengan beberapa kesimpulan spesifik;

1)umumnya mahasiswa memulai komunikasi sebagaimana mereka memberikan gambaran tentang diri dan orang lain;2) pengenalan diri dan orang lain dipercayai sebagai pemandu mereka dalam membangun komunikasi sosialnya, khususnya konteks antarbudaya; 3)konsep diri (dan orang lain) pada akhirnya memberikan identitas mengenai tipe komunikasi antarbudaya mahasiswa, baik dalam konteks pertemanan maupun alasan memilih teman antarbudaya.
\end{abstract}

Kata Kunci: konsep diri, komunikasi, komunikasi antarbudaya.

\section{A. Pendahuluan}

Komunikasi, sebuah istilah yang mudah diucapkan. Bahkan setiap orang menggunakan istilah tersebut dalam kesehariannya. Dalam hubungan sosial misalnya, kita sering mendengarkan ungkapan "bangunlah komunikasi yang baik dengannya". "Apakah anda sudah melakukan komunikasi dengan mereka" dan sebagainya.

Dalam konteks yang lebih luas, kita juga sering beranggapan bahwa, sebuah persoalan akan dapat diselesaikan dengan "berkomunikasi yang baik".Atau, mungkin disebabkan satu dan lain hal kita akan mengatakan "saya lagi tidak mau berkomunikasi dengan siapapun". Atau, "saya tidak mau menemuinya karena saya lagi malas berkomunikasi" (Ibrahim, 2015: 19).

Beberapa contoh pernyataan di atas sesungguhnya merupakan realitas yang sering berlaku dalam komunikasi kita. Dimana kita menganggap komunikasi sebagai sebuah aktivitas yang tegas, terencana dan terpisah dari aktivitas hidup yang lainnya. Dengan realitas demikian, kita juga sering menganggap bahwa, ketika orang lain tidak mengikuti apa yang kita sarankan maka kita akan cendrung menganggap bahwa mereka itu tidak paham alias "bodoh". Atau paling ekstrim lagi adalah, kita akan cendrung menganggap salah 
terhadap orang lain yang bersikap beda (tidak sesuai) dengan apa yang kita harapkan.

Sebagai makhluk sosial yang lahir dan diciptakan dengan berbagai potensi yang saling berbeda, maka tidak pantas bagi kita untuk menafikan setiap perbedaan itu. Meskipun pada kenyataannya, seringkali perbedaan itu menjadi masalah bahkan menimbulkan konflik. Inilah realitas sosial kita yang berjalan seiring dengan kehendak-Nya (sunnatullah) yang sengaja menciptakan kita dengan perbedaan-perbedaan, yang dengan perbedaan itu kita mesti saling berkomunikasi (lita ’arafu) ${ }^{1}$.

Dalam perkembangan ilmu pengetahuan modern, lita arafu itulah sesungguhnya yang melahirkan ilmu komunikasi, di mana salah satu unsur yang mesti ada di dalamnya adalah diri (sebagai komunikator) dan orang lain (sebagai komunikan). Seperti apa sesungguhnya kita mampu mengenal diri dan orang lain, maka seperti itulah komunikasi akan kita bangun. Dalam konteks masyarakat yang berbeda budaya, kita dituntut untuk mampu mengenal diri dsan orang lain yang berbeda budaya dengan baik dan benar. Sebab dengan inilah kita mampu membangun komunikasi yang baik antar

Komunikasi dan perbedaan adalah dua hal yang tak terpisahkan. Komunikasi menjadi penting dengan adanya realitas perbedaan-perbedaan (apapun bentuknya). Sebaliknya, perbedaan budaya di satu sisi, dan terhindar dari konflik antarbudaya pada sisi lain. Karena itulah, penelitian "mengenal diri dan orang lain dalam komunikasi antarbudaya" menjadi penting dilakukan.

Penelitian ini dilakukan di kampus IAIN Pontianak, dengan objek studi mahasiswa Komunikasi Penyiaran Islam (KPI) angkatan 2011/2012 yang sedang mengambil matakuliah Komunikasi Antarbudaya. Pemilihan sampel menggunakan teknik refresentatif sampling (25\% dari jumlah keseluruhan peserta kelas), dengan teknik pengumpulan data menggunakan korespondensi dan penugasan. Analisis data menggunakan model analisis interaktif milik Miles dan Huberman, guna menjawab pertanyaan utama mengenai "Konsep Diri dalam Komunikasi Antarbudaya".

\section{B. Konsep Diri dan Persepsi Antarbudaya}

Diri, dalam bahasa inggrisnya disebut dengan self. Sedangkan persepsi diri disebut dengan self perception, dan konsepsi diri disebut dengan self conception.Secara sederhana persepsi adalah proses aktif dan kreatif manusia dalam mengkonstruk suatu gambar mengenai dunia, benda, situasi, peristiwa,

\footnotetext{
menjadi prasyarat bagi pentingnya proses untuk saling memahami (komunikasi). Begitulah intisari pesan yang mesti difahami dari Q.S. 49: 13.
} 
diri dan orang lain di sekitar kita. la adalah proses internal yang memungkinkan kita memilih, mengorganisir dan menafsirkan rangsangan dari lingkungan kita, dan proses tersebut mempengaruhi perilaku kita, bahkan ia adalah inti dari komunikasi (Deddy Mulyana, 2002)

Pemahaman tentang diri pribadi ini berkembang sejalan dengan perubahan yang terjadi dalam hidup kita. Kita tidak terlahir dengan pemahaman akan siapa diri kita, tetapi prilaku kita selama ini memainkan peranan penting bagaimana kita membangun pemahaman diri pribadi ini (Sendjaja, dkk, 1998). Sedangkan orang lain dalam bahasa inggrisnya disebut dengan the other. Persepsi terhadap orang lain dikenal dengan istilah perception to the other, dan konsepsi terhadap orang lain disebut dengan conception to the other.

Persepsi pada akhirnya akan membentuk konsepsi tertentu terhadap apa yang dipersepsi. Karena itu persepsi dan konsepsi senantiasa pengaruh mempengaruhi. Persepsi yang salah akan membuat kelirunya konsepsi. Sebaliknya konsepsi yang salah juga akan membuat persepsi yang tidak benar. Jika digambarkan dalam bagan, maka persepsi dan konsepsi bagaikan lingkaran komunikasi ayam dan telur ayam, yang tidak pernah tau mana yang lebih dahulu keduanya.

Terlepas dari itu, persepsi dan konsepsi terhadap diri akan menentukan pola dan bentuk komunikasi yang akan dilakukan. Ketika persepsi dan konsepsi terhadap diri baik dan benar, maka komunikasi yang dilangsungkan akan mungkin berjalan dengan baik, positif, penuh percaya diri dan maksimal. Sebaliknya jika persepsi dan konsepsi diri kurang baik dan keliru, maka komunikasi yang terbangun akan bersifat tidak maksimal dan kurang percaya diri (Ibrahim, 2010).

Sebagai sebuah proses stimuli untuk memberi makna terhadap suatu objek yang dipersepsi dan dikonsepsi, ada beberapa katagori besar objek yang dapat dipersepsi. Pertama, terhadap lingkungan fisik, kongkrit dan dapat diamati secara nyata; kedua, terhadap objek-objek dan kejadian sosial yang kita alami dan saksikan dalam lingkungan sosial kita. Persepsi sosial ini senantiasa dipengaruhi oleh pengalaman (field of eksperience) seseorang, bersifat selektif, bersifat dugaan karena mempersepsi juga adalah menduga makna dari suatu objek yang diamati, dipersepsi dan dikonsepsi. Persepsi juga bersifat evaluatif dan kontekstual.Karena itulah Porter dan Samovar (dalam Roger dan Stienfatt, 1986) ketika menjelaskan mengenai persepsi dalam komunikasi menyatakan bahwa "Kemiripan budaya dalam persepsi memungkinkan pemberian makna yang mirip pula terhadap suatu objek sosial atau suatu 
peristiwa", termasuklah terhadap diri dan orang lain.

Adapun komunikasi antarbudaya itu adalah Intercultural communication, yang bermakna suatu aktivitas, atau proses sosial yang melibatkan peserta atau komunikannya dari latar belakang budaya yang saling berbeda.

Andrea L Rich dan Dennis M. Ogawa misalnya menyatakan dalam buku Intercultural Communication, A Reader, bahwa komunikasi antarbudaya berarti komunikasi antara orang-orang dari kultur yang berbeda baik kepercayaan, nilai atau cara berperilaku. Karena itu bentuk komunikasi antarbudaya meliputi komunikasi antar subbudaya, komunikasi antar etnis, komunikasi antarras, komunikasi antar agama, komunikasi internasional, komunikasi propesi, komunikasi gender dan sebagainya.

Menurut Devito (1997), sedikitnya ada tiga katagorisasi yang menggambarkan hakikat komunikasi antarbudaya, yakni; pertama, wujudnya budaya dan sub budaya yang saling berbeda dan terlibat dalam proses komunikasi dan hubungan sosial, termasuklah adat istiadat, kepercayaan, agama dan sebagainya. Kedua, terjadinya proses pengalihan budaya satu dengan lainnya dalam hubungan sosial baik melalui proses engkulturasi maupun akulturasi. Bahkan juga bisa melalui proses segregasi dan amalgamasi (Shamsul Amri Baharudin, 2007).
Ketiga, sebuah proses sosial yang melibatkan orang-orang dari latar belakang sosial dan budaya yang saling berbeda, baik antar (inter-cultural), antara sesama (intra-cultura), hingga lintas (across-cultural).

Kesemua katagori budaya yang berbeda di atas akan menentukan dan membedakan cara komunikasi mereka masing-masing. Perbedaan etnis, agama, latar belakang sosial, ekonomi, politik, pendidikan dan sebagai akan membuat setiap orang berbeda dalam anutan nilai yang dipercayai dan digunakan. Aturan dan nilai budaya yang berbeda itulah yang akan menuntun setiap orang berkomunikasi dan membangun hubungan sesama. Nilai dan anutan itulah yang membolehkan atau tidak membolehkan cara komunikasi tertentu dilakukan, baik dalam memilih simbol dan lambang komunikasi maupun bentuk dan pola komunikasi yang dipakai.

Perbedaan latar belakang budaya seseorang bukan saja akan mempersulit dalam proses membangun komunikasi antarbudaya, akan tetapi juga memungkinkan setiap orang berbeda dalam mempersepsi diri dan orang lain. Padahal, setiap orang dan komunikasi yang dibangun sangat bergantung pada persepsi dan konsepsi terhadap diri dan orang lain.

Terakhir, bicara diri dan orang lain dalam komunikasi mengharuskan kajian mengenai komunikasi ke dalam diri 
pribadi yang dikenal dengan istilah Intrapersonal communication. Sedangkan mengenal orang lain dalam komunikasi merupakan bagian dari perbincangan komunikasi antar individu yang dikenal dengan istilah inter-personal communication. Untuk kedua bentuk komunikasi ini (intra dan inter) dapat dilihat dalam banyak buku ilmu komunikasi, a.I. Dedy Mulyana, 2002, IImu Komunikasi: Suatu pengantar, Yoseph Devito, 1997. Komunikasi Antara Manusia; Alo Liliweri, 2003. Dasar-dasar Komunikasi Antarbudaya; Ibrahim, 2009. Komunikasi Antarbudaya; dan lain-lain.

Dengan memahami konsep komunikasi intra dan inter-personal, maka kajian mengenai diri dan orang lain dalam komunikasi akan dapat diselesaikan, apalagi untuk konteks komunikasi antarbudaya.

\section{Konsep Diri dalam Komunikasi}

Dalam rangka pengembangan disiplin ilmu komunikasi, khususnya Konsep Diri dalam Komunikasi Antarbudaya, kajian ini mengambil sampel kasus pada Mahasiswa Komunikasi Penyiaran Islam (KPI) angkatan 2011/ 2012. Untuk memudahkan dalam pemaparan data mengenai Konsep Diri dalam Komunikasi, pembahasan berikutnya disajikan dalam empat bagian utama, yakni mengenal diri, mengenal orang lain, alasan memilih teman, serta analisis
Konsep Diri (persepsi dan konsepsi) dalam komunikasi antarbudaya.

\section{Mengenal Diri dalam Komunikasi Antarbudaya}

Banyak orang yang dengan mudah mendeskripsikan mengenai orang lain, kelebihan dan kekurangannya. Akan tetapi tidak banyak orang yang mampu mendeskripsikan secara baik dan memadai mengenai siapa diri, apa kelebihan dan kekurangan diri dan sebagainya. Inilah yang disebut dengan problem persepsi dan konsepsi diri, dimana banyak dari kita yang sulit dalam mengenali diri sendiri.

Pemahaman yang baik terhadap diri akan menentukan keberhasilan mengerahkan segala potensi komunikasi yang ada dalam diri seseorang. Kemampuan mengenal diri sendiri, juga merupakan kunci untuk mengatasi kekurangan dan kelemahan yang ada dalam diri seseorang.

Dalam kajian komunikasi, pengenalan terhadap diri dan orang lain, biasa diistilahkan dengan persepsi dan konsepsi diri. Persepsi dan konsepsi yang baik dan positif terhadap diri dan orang lain, akan membentuk komunikasi yang baik dan positif pula dalam membangun hubungan komunikasi dengan orang lain. Sebaliknya persepsi dan konsepsi yang jelek dan negatif terhadap diri dan orang lain, juga akan menjadikan komunikasi yang janggal, penuh curiga, ugal-ugalan 
dan meremehkan dalam hubungan antar manusia. Pantaslah ada ungkapan komunikasi yang menyatakan bahwa, "orang cendrung akan berkomunikasi sebagaimana persepsi dan konsepsi yang ia miliki terhadap komunikasi yang akan ia lakukan". Karena itu,prinsip komunikasi mempercayai bahwa setiap perilaku komunikasi akan senantiasa dilangsungkan dengan melibatkan prediksi-prediksi (lihat dalam Deddy Mulyana, 2002: 104).

Ungkapan tersebut, jika dilanjutkan akan berarti bahwa, tatkala kita merasa diri kita lebih hebat, lebih baik dan lebih pintar dari orang yang akan kitahadapi, maka tentu kita akan melakukan komunikasi dengan santai, penuh percaya diri, terkadang sembarangan dan sombong. Sebaliknya jika kita merasakan diri kita orang rendahan, miskin, jelek, maka kitaakancendrung melakukan komunikasi dengan pelan, menunduk, malu, dengan bahasa terbata-bata dan tidak percaya diri.

Mengenal diri, atau mengetahui diri dan potensi diri dengan baik sangat penting dalam sebuah komunikasi, apalagi dalam konteks antarbudaya. Pengetahuan yang baik dan benar tentang diri akan sangat membantu dalam sebuah proses komunikasi yang dilakukan. Sebab, setiap orang sesungguhnya akan tampil dalam berkomunikasi sebagaimana ia mengenal diri dan potensi diri di hadapan lawan komunikasinya. Artinya bahwa, orang yang mengenal dirinya sebagai punya kemampuan yang baik dalam komunikasi, maka ia akan tampil berkomunikasi dengan kemampuan yang maksimal. Sebaliknya, orang yang mengenal diri sebagai tidak punya kecakapan dalam berkomunikasi, maka ia akan tampil sebagai orang yang tidak bisa apa-apa dalam komunikasi dan hubungan sosial. Karena itu, kajian mengenal diri dalam komunikasi antarbudaya menjadi bagian utama dan sangat penting dalam perbincangan komunikasi antarbudaya.

Berikut ini beberapa data pengenalan diri yang dapat diberikan oleh mahasiswa peserta kelas Komunikasi Antarbudaya pada Program Komunikasi Penyiaran Islam (KPI) angkatan 2011/2012. Ada empat aspek pengenalan yang ditampilkan dalam setiap tabel di bawah ini, yakni mengenal sifat diri (tabel C. 1a), mengenal kelebihan dan kekurangan diri (tabel C.1b), mengenal hal-hal yang disukai dan tidak disukai diri (tabel C.1c), serta mengenal kemampuan komunikasi diri dan pilihan bahasa dalam komunikasi (tabel C. 1d).

Untuk memudahkan pemahaman terhadap data (sebagaimana ditabelkan), maka paparan keempat aspek pengenalan tersebut disajikan dalam tiga kolom utama; kolom 1 (aspek pengenalan), kolom 2 (deskripsi diri) dan kolom 3 (tipe komunikasi). 
Tabel: C. 1a

Mengenal Sifat Diri dalam Komunikasi Antarbudaya

\begin{tabular}{|c|c|c|}
\hline $\begin{array}{l}\text { ASPEK } \\
\text { PENGENALAN }\end{array}$ & DESKRIPSI DIRI & $\begin{array}{l}\text { TIPE } \\
\text { KOMUNIK } \\
\text { ASI }\end{array}$ \\
\hline \multirow[t]{3}{*}{ Sifat diri } & $\begin{array}{l}\text { Saya termasuk } \\
\text { orang mudah } \\
\text { akrab, tetapi tidak } \\
\text { mudah bergaul } \\
\text { karena sifat } \\
\text { pemalu yang } \\
\text { besar.., enggan } \\
\text { memulai } \\
\text { komunikasi. Saya } \\
\text { orang yang keras } \\
\text { kepala, bertahan } \\
\text { dengan prinsip } \\
\text { dan tidak ragu- } \\
\text { ragu..(agt) }\end{array}$ & Selektifitas \\
\hline & $\begin{array}{l}\text { Saya adalah } \\
\text { orang yang santai, } \\
\text { disiplin dengan } \\
\text { waktu dan ramah } \\
\text { pada semua } \\
\text { orang (dh) }\end{array}$ & $\begin{array}{l}\text { Membuka } \\
\text { diri }\end{array}$ \\
\hline & $\begin{array}{l}\text { Saya .... selalu } \\
\text { berusaha ada di } \\
\text { setiap teman } \\
\text { membutuhkan } \\
\text { bantuan, agar } \\
\text { saya dapat } \\
\text { menjadi orang } \\
\text { yang bermanfaat } \\
\text { bagi orang } \\
\text { lain. ..saya } \\
\text { terkadang orang } \\
\text { yang malas dalam } \\
\text { melakukan } \\
\text { sesuatu. ..saya } \\
\text { orang yang keras } \\
\text { kepala.... (Rt) }\end{array}$ & $\begin{array}{l}\text { Nubuat } \\
\text { yang } \\
\text { dipenuhi } \\
\text { sendiri }\end{array}$ \\
\hline
\end{tabular}

Pada bagian lain, pengenalan diri juga menyangkut pemahaman terhadap kelebihan dan kekurangan pada diri sendiri, yang dengan kelebihan dan kekurangan itu, sesungguhnya setiap kita akan melakukan komunikasi dan interaksi dengan orang lain. Berikut beberapa data praktis yang didapatkan pada mahasiswa peserta kelas Komunikasi Antarbudaya
Program Studi KPI angkatan tahun $2011 / 2012$

Tabel: C. $1 \mathrm{~b}$

Mengenal Kelebihan dan Kekurangan Diri dalam Komunikasi Antarbudaya

\begin{tabular}{|c|c|c|}
\hline $\begin{array}{l}\text { ASPEK } \\
\text { PENGENALAN }\end{array}$ & DESKRIPSI DIRI & $\begin{array}{l}\text { TIPE } \\
\text { KOMUNIKASI }\end{array}$ \\
\hline \multirow[t]{3}{*}{$\begin{array}{l}\text { Kelebihan dan } \\
\text { kekurangan diri }\end{array}$} & $\begin{array}{l}\text {..kelebihan yang } \\
\text { saya miliki yakni saya } \\
\text { selalu ada disaat } \\
\text { mereka } \\
\text { membutuhkan. } \\
\text { Disaat mereka } \\
\text { merasa kesusahan } \\
\text { maka saya } \\
\text { merasakan hal yang } \\
\text { demikian juga dan } \\
\text { berusaha untuk } \\
\text { mencarikan jalan } \\
\text { keluar dari masalah } \\
\text { yang dihadapi } \\
\text { mereka....saya } \\
\text { mempunyai sifat } \\
\text { yang egois dan } \\
\text { pendendam (Rf) }\end{array}$ & $\begin{array}{l}\text { Nubuat yang } \\
\text { dipenuhi } \\
\text { sendiri }\end{array}$ \\
\hline & $\begin{array}{l}\text { Sifat yang menurutku } \\
\text { baik di dalam } \\
\text { diriku ... anak yang } \\
\text { selalu tersenyum dan } \\
\text { bersemangat dalam } \\
\text { segala hal, } \\
\text { khususnya dalam } \\
\text { menghafalkan qur'an. } \\
\text { Sifat } \\
\text { burukku..terkadang } \\
\text { tidak bisa mengontrol } \\
\text { emosiku,..lepas } \\
\text { kendali, ..perlahan } \\
\text { aku mencoba untuk } \\
\text { menutupi sifat } \\
\text { burukku tersebut } \\
\text { (Irw) }\end{array}$ & $\begin{array}{l}\text { Nubuat yang } \\
\text { dipenuhi } \\
\text { sendiri }\end{array}$ \\
\hline & $\begin{array}{l}\text { Kelebihanku tidak } \\
\text { pernah lupa untuk } \\
\text { senantiasa membaca } \\
\text { ayat suci Al-Quran. } \\
\text { Kekuranganku egois, } \\
\text { keras kepala, mudah } \\
\text { tersinggung, suka } \\
\text { mengulur-ulur waktu } \\
\text { (Sa) }\end{array}$ & Percaya diri \\
\hline
\end{tabular}

Sebagai bagian penting dalam komunikasi, pengenalan diri dalam komunikasi juga dapat dianalisis dari kemampuan memberikan deskripsi diri 
mengenai hal-hal yang disukai dan tidak

disukai dalam komunikasi. Berikut

beberapa datanya.

Tabel: C. 1c

Mengenal Hal yang Disukai dan tidak

Disukai dalam Komunikasi Antarbudaya

\begin{tabular}{|c|c|c|}
\hline $\begin{array}{l}\text { ASPEK } \\
\text { PENGENALAN }\end{array}$ & DESKRIPSI DIRI & $\begin{array}{l}\text { TIPE } \\
\text { KOMUNIKASI }\end{array}$ \\
\hline \multirow[t]{3}{*}{$\begin{array}{l}\text { Hal yang } \\
\text { disukai dan } \\
\text { tidak disukai }\end{array}$} & $\begin{array}{l}\text { Hal yang paling } \\
\text { disukai..seseorang } \\
\text { menyapa dengan } \\
\text { ramah dan } \\
\text { berbicara secara } \\
\text { dewasa.., menyapa } \\
\text { dengan bahasa } \\
\text { keakraban,.. tidak } \\
\text { menjatuhkan.... Hal } \\
\text { yang paling saya } \\
\text { benci..seseorang } \\
\text { bersikap acuh dan } \\
\text { arogan, tidak } \\
\text { bertanggung } \\
\text { jawab.... (Dd) }\end{array}$ & Membuka diri \\
\hline & $\begin{array}{l}\text { Hal yang } \\
\text { sukai..menonton, } \\
\text { baca komik dan } \\
\text { novel, jalan-jalan, } \\
\text { kuliner, sleeping. } \\
\text { Saya tidak suka } \\
\text { sifat yang manja } \\
\text { dengan orang } \\
\text { lain, ..tidak suka } \\
\text { dibohongi, dalam } \\
\text { pertemanan tidak } \\
\text { suka ada rahasia- } \\
\text { rahasiaan, ..tidak } \\
\text { suka menunggu.. } \\
\text { (Mtr) }\end{array}$ & Selektifitas \\
\hline & $\begin{array}{l}\text {..saya itu orangnya } \\
\text { sangat suka } \\
\text { dengan sesuatu } \\
\text { yang berbau } \\
\text { dramatis, } \\
\text { romantic... fanatik } \\
\text { dengan warna } \\
\text { putih. Sedangkan } \\
\text { yang paling saya } \\
\text { benci adalah } \\
\text { menunggu, karena } \\
\text { menurut saya } \\
\text { waktu itu sangat } \\
\text { berharga, } \\
\text { menunggu.. } \\
\text { sebagai } \\
\text { penghinaan, tapi } \\
\text { kesalahan terbesar } \\
\text { saya adalah sangat } \\
\text { suka ditunggu (Mry) }\end{array}$ & $\begin{array}{l}\text { Nubuat yang } \\
\text { dipenuhi } \\
\text { sendiri }\end{array}$ \\
\hline
\end{tabular}

Aspek terakhir yang penting dilihat

dalam rangka mengenal diri dalam

Komunikasi antarbudaya adalah

menyangkut kemampuan komunikasi dan

pilihan bahasa yang digunakan. Berikut beberapa datanya.

Tabel: C. 1d

Mengenal Kemampuan Komunikasi diri dan Pilihan Bahasa

\begin{tabular}{lll}
\hline ASPEK & DESKRIPSI & TIPE \\
PENGENALAN & DIRI & KOMUNIKASI \\
\hline Kemampuan & Sehari-hari & Membuka diri \\
komunikasi dan & berkomunikasi & \\
pilihan bahasa & menggunakan & \\
yang digunakan & bahasa Melayu. & \\
& Karena ayahku & \\
& keturunan & \\
& Melayu. Aku & \\
& bisa berbicara & \\
& dengan nada & \\
& keras, tegas jika & \\
& situasi harus & \\
& demikian. Aku & \\
& juga bisa bicara & \\
& dalam nada & \\
& yang lembut & \\
& sesuai & \\
& konteknya.. & \\
& (Agt)
\end{tabular}

Kalau soal gaya Selektifitas bahasa yang saya gunakan, rasanya saya selalu berusaha untuk sesopan mungkin dengan siapapun, ....say a sangat menjunjung tinggi akhlak, sopan santun dan lebih mementingkan perasaan orang lain (Mry)

Dalam pergaulan sehari-hari menggunakan bahasa Indonesia, dan kadang juga menggunakan bahasa daerah. Namun lebih mengutamakan perasaan orang lain. Apalagi 
jikalau lawan

bicara saya

adalah lebih tua,

saya akan

berhati-hati

dalam berbicara

(Dh)

2. Mengenal Orang Lain dalam Komunikasi Antarbudaya

Persepsi dan konsepsi terhadap orang lain pada dasarnya hampir sama dengan terhadap diri sendiri. Persepsi dan konsepsi terhadap orang lain, selain referensi dari luar dirinya dalam memandang orang lain, ia juga dipengaruhi oleh frame of referense dan field of eksperience dalam diri seseorang. Karenanya ada beberapa prinsip yang berlaku dalam mempersepsi dan mengkonsepsi orang lain dalam komunikasi antarbudaya.

Pertama, adanya kemiripan, kedekatan dan kelengkapan pada struktur objek dan kejadian. Struktur dan kejadian dimaksud dalam mempersepsi dan mengkonsepsi orang lain tentu saja mereka yang berada di luar pribadi yang mempersepsi dan mengkonsepsinya.

Kedua, kita cendrung mempersepsi dan mengkonsepsi suatu ransangan atau kejadian yang terdiri dari objek dan latar belakangnya. Semakin mirip suatu ransangan dan kejadian dengan ojek dan latar belakangnya, maka semakin mudah dan semakin baiklah persepsi dan konsepsi yang diberikan terhadap orang lain. Meskipun harus ditegaskan bahwa, tidak ada persepsi yang objektif. Semua persepsi pada dasarnya adalah subjektif. Andrea L Rich telah mengomentari ini dengan pernyataannya "persepsi pada dasarnya mewakili keadaan fisik dan psikologis individu, alih-alih menunjukkan karakteristik dan kualitas mutlak objek yang dipersepsi (Deddy Mulyana, 2002).

Sebagaimana pentingnya mengenal diri dalam komunikasi (lihat kajian sebelumnya), mengenal orang lain sesungguhnya juga merupakan bagian yang sama pentingya dalam sebuah komunikasi sosial dan antarbudaya yang dilakukan. Karena pada dasarnya, setiap orang akan mengkonstruks pola komunikasinya dengan seseorang mengikuti apa yang ia kenali/konsepsi tentang orang yang dia hadapi.

Sebagai contoh, jika seseorang menganggap bahwa orang yang akan ditemuinya adalah orang hebat, berkedudukan, punya nama, cantik atau tampan, maka ia akan menyiapkan diri berkomunikasi dengan segala kemampuan yang dimilikinya. Bahkan seringkali ia tampil dalam komunikasi sebagai orang yang sopan, rendah diri, dan malu-malu. Atau mungkin terkadang kurang percaya diri karena konsepsi terhadap orang lain (lawan komunikasinya) terlalu tinggi dibandingkan diri sendiri.

Sebaliknya, jika kita beranggapan bahwa seseorang yang akan ditemui adalah orang rendahan, tidak berpendidikan, status sosial rendahan, bahkan pengemis atau peminta-peminta, maka 
kita cendrung untuk membangun komunikasi dengan serampangan, ugal-ugalan, semena-mena, bahkan terkadang angkuh dan sombong.

Pentingnya aspek mengenal orang dalam komunikasi membuat peneliti merasa penting untuk melihat bagaimana mahasiswa peserta kelas Komunikasi Antarbudaya pada Program Studi Komunikasi Penyiaran Islam angkatan 2011/2012 STAIN Pontianak mampu mengenal orang lain dalam konteks pertemanan antarbudaya. Berikut beberapa data yang dihasilkan dari latihan memilih teman antarbudaya pada mahasiswa KPI angkatan 2011/2012 Jurusan Dakwah STAIN Pontianak, khusus yang telah mengikuti kuliah Komunikasi Antarbudaya.

Tabel: C. $2 a$

Mengenal Sifat baik dan tidak baik Teman dalam Komunikasi Antarbudaya

\begin{tabular}{lll}
\hline ASPEK & DESKRIPSI ORANG & TIPE \\
PENGENALAN & LAIN (TEMAN & KOMUNIKASI \\
& ANTARBUDAYA) & \\
\hline Sifat baik dan & kelebihannya..dalam & Membuka diri \\
tidak baik pada & berbicara, ia orangnya & \\
teman (orang & asik, mudah bergaul dan & \\
lain) & menemukan teman baru & \\
& dengan gaya bahasa & \\
& yang sedikit bebas. & \\
& Kekurangannya..saat dia & \\
& mempunyai masalah & \\
& pribadi, ia tidak bisa & \\
& menyelesaikannya, & \\
& cenderung mudah & \\
& menyerah dan tidak mau & \\
& menyelesaikannya... & \\
& (Ddn) & \\
& ..sifatnya agak pemalu, & Percaya diri \\
& sabar, perhatian, tidak & (self \\
& sombong, baik, sholeha, & confidence) \\
& terbuka, ..la juga lemah- & \\
& lembut, dalam bicara & \\
& baik dan teratur.. & \\
& Kelebihannya & \\
&
\end{tabular}

pema'af, ..., percaya diri, dan giat belajar.

Kekurangannya tidak

mau disalahkan. ..bisa melihat kesalahan orang lain, tetapi tidak melihat kesalahan dirinya sendiri. (Mnt)

..dia itu anak yang ramah dan pengertian. Tapi jika

Selektifitas ada yang mengganggunya, sifat buruknya keluar yaitu mudah tersinggung alias sensitif dan mudah menangis (Irw)

Kemampuan mengenal orang lain dan membangun komunikasi yang baik dalam konteks pertemanan antarbudaya juga penting dilihat dari aspek pengenalan terhadap sesuatu yang spesifik dan disukai dan atau tidak disukai oleh teman (orang lain) yang berbeda budaya. Berikut beberapa datanya.

Tabel: C. $2 b$

Mengenal yang Disukai dan tidak Disukai Teman dalam Komunikasi Antarbudaya

\begin{tabular}{lll}
\hline ASPEK & DESKRIPSI & TIPE \\
PENGENAL & ORANG LAIN & KOMUNIKA \\
AN & (TEMAN & SI \\
& ANTARBUDAYA) & \\
\hline Yang paling & ..la menyenangi & Selektifitas \\
disukai dan & musik dangdut, & \\
tidak disukai & senang kepada & \\
oleh teman & orang yang dapat & \\
(orang lain) & mengerti & \\
& mengenai & \\
& keadaan, situasi & \\
& dan kondisi yang & \\
& dihadapinya. & \\
& Yang paling tidak \\
& disenanginya & \\
& yakni orang yang \\
& tidak dapat \\
& mengerti \\
& keadaannya, \\
& orang yang tidak \\
& bisa menjaga \\
& sikap atau \\
&
\end{tabular}




\begin{tabular}{|c|c|}
\hline $\begin{array}{l}\text { kesopanannya. } \\
\text { (Rt) } \\
\text { la paling senang } \\
\text { jalan-jalan... Sikap } \\
\text { yang paling } \\
\text { disukainya adalah } \\
\text { bisa membuat } \\
\text { orang lain } \\
\text { tersenyum, } \\
\text { disiplin, tidak } \\
\text { mudah marah } \\
\text { atau tersinggung, } \\
\text { tidak pernah } \\
\text { mengulur-ulur } \\
\text { waktu dalam } \\
\text { mengerjakan } \\
\text { sesuatu...Yang } \\
\text { paling dibencinya } \\
\text { ialah orang yang } \\
\text { salah } \\
\text { mempersepsikan } \\
\text { dirinya, yang } \\
\text { bertele-tele dan } \\
\text { tidak teliti dalam } \\
\text { mengerjakan } \\
\text { sesuatu...(Mry) }\end{array}$ & $\begin{array}{l}\text { Nubuat yang } \\
\text { dipenuhi } \\
\text { sendiri }\end{array}$ \\
\hline $\begin{array}{l}\text {..dia menyukai } \\
\text { sesuatu yang } \\
\text { berhubungan } \\
\text { teknologi } \\
\text { informasi. ..dia } \\
\text { juga menyukai } \\
\text { orang yang punya } \\
\text { keinginan untuk } \\
\text { maju. Orang yang } \\
\text { memiliki } \\
\text { kepedulian } \\
\text { sesama. Dia tidak } \\
\text { suka dengan } \\
\text { orang yang suka } \\
\text { mematahkan } \\
\text { semangat orang } \\
\text { lain, orang yang } \\
\text { tidak mau peduli } \\
\text { sesama, serta } \\
\text { orang yang jorok.. } \\
\text { (Agt) }\end{array}$ & $\begin{array}{l}\text { Membuka } \\
\text { diri }\end{array}$ \\
\hline
\end{tabular}

\section{Alasan Memilih Teman dalam}

\section{Komunikasi Antarbudaya}

Sebagai makhluk sosial-apalagi dalam konteks antarbudaya, kita akan sampai pada sebuah pertimbangan dalam memilih teman. Semua orang tentunya mempunyai alasan dan pertim- bangan tersendiri dalam memilih teman (sahabat) dalam sebuah proses komunikasi. Alasan atau pertimbangan memilih teman atau sahabat ini sesungguhnya merupakan kelanjutan/atau paling tidak rangkaian dalam pengenalan diri dan orang lain dalam komunikasi antarbudaya. Berikut beberapa data yang dihasilkan dari mahasiswa peserta kelas Komunikasi Antarbudaya pada Program Studi Komunikasi Penyiaran Islam angkatan 2011/2012.

Tabel: C. 3

Mengenal Alasan Memilih Teman

dalam Komunikasi Antarbudaya

\begin{tabular}{|c|c|c|}
\hline $\begin{array}{l}\text { ASPEK } \\
\text { PENGENALAN }\end{array}$ & $\begin{array}{l}\text { DESKRIPSI } \\
\text { ORANG LAIN } \\
\text { (TEMAN } \\
\text { ANTARBUDAYA) }\end{array}$ & $\begin{array}{l}\text { TIPE } \\
\text { KOMUNIKASI }\end{array}$ \\
\hline \multirow[t]{2}{*}{$\begin{array}{l}\text { Alasan/ } \\
\text { pertimbangan } \\
\text { memilih teman }\end{array}$} & $\begin{array}{l}\text {..aku memilih } \\
\text { teman yang bisa } \\
\text { memberikan hal } \\
\text { positif.., ..aku juga } \\
\text { menyukai teman } \\
\text { yang berkatanya } \\
\text { tidak kasar dan } \\
\text { menyinggung } \\
\text { orang lain (Agt) }\end{array}$ & $\begin{array}{l}\text { Pribadi \& } \\
\text { keakraban }\end{array}$ \\
\hline & $\begin{array}{l}\text { Saya suka orang } \\
\text { yang dapat } \\
\text { memberi contoh } \\
\text { atau masukan } \\
\text { untuk mengajak } \\
\text { melakukan hal-hal } \\
\text { yang positif baik } \\
\text { itu dalam } \\
\text { pergaulan } \\
\text { dilingkungan } \\
\text { keluarga, } \\
\text { masyarakat } \\
\text { (sosial), bangsa } \\
\text { dan negaradan } \\
\text { lebih } \\
\text { mengutamakan } \\
\text { kepentingan } \\
\text { umum dibanding } \\
\text { kepentingan } \\
\text { pribadi } \\
\text { (golongan). Dalam } \\
\text { bergaul saya tidak } \\
\text { memandang etnis, } \\
\text { suku maupun }\end{array}$ & $\begin{array}{l}\text { Sosial \& } \\
\text { Keterlibatan }\end{array}$ \\
\hline
\end{tabular}




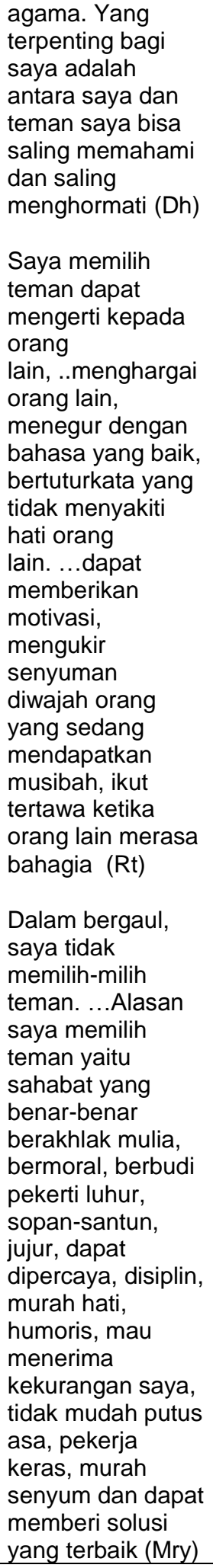

Dalam bergaul, saya tidak memilih-milih teman. ...Alasan saya memilih teman yaitu sahabat yang benar-benar berakhlak mulia, bermoral, berbudi pekerti luhur, sopan-santun, jujur, dapat dipercaya, disiplin, murah hati, humoris, mau menerima kekurangan saya, tidak mudah putus asa, pekerja keras, murah senyum dan dapat memberi solusi yang terbaik (Mry)

Beberapa contoh pernyataan di atas memberikan gambaran bahwa setiap orang akan berkomunikasi seperti apa yang mereka gambarkan terhadap diri dan orang lain. Setiap orang juga akan menentukan kriteria teman atau sahabat yang diinginkannya sesuai dengan apa yang mereka pahami terhadap diri, sifat diri, serta hal-hal yang baik dan disukainya. Karena, semua bentuk penilaian diri, penilaian terhadap orang lain, serta alasan-alasan atau pertimbangan dalam memilih teman akan sangat menentukan dalam membangun komunikasi antar sesama, khususnya dalam konteks komunikasi antarbudaya.

\section{Analisis Konsep Diri dalam Komunikasi}

Komunikasi yang kita bangun dalam kehidupan sosial sehari-hari sesungguhnya juga ditentukan oleh bagaimana kita melihat, menilai dan memberikan persepsi dan konsepsi terhadap orang lain (partisipan dalam komunikasi kita). Beberapa bentuk persepsi dan konsepsi terhadap orang lain dapat dilihat dari paling tidak dua kebiasaan kita memberikan deskripsi/gambaran terhadap seseorang; yakni sifat baik atau tidak baik, serta apa yang orang lain sukai dan orang lain tidak sukai.

Untuk melakukan analisis mengenai persepsi dan konsepsi terhadap orang lain dalam komunikasi, peneliti meminjam konsep yang ditawarkan oleh Jalaluddin Rakhmat dalam bukunya Psikologi Komunikasi. Menurutnya, "the fact is that we can understand ourselves by starting 
from the other, or from others, and only by starting from them". Dengan kata lain, untuk sebuah komunikasi yang baik dan efektif, kita mesti memulainya denganmengenal diri kita dari (pandangan) orang lain lebih dahulu.

Pentingnya persepsi dan konsepsi terhadap orang lain dapat dilihat dalam sebuah contoh yang diceritakan oleh Harry Stack Sullivan (dalam Jalaluddin Rakhmat, 2004: 101) bahwa, jika kita diterima oleh orang lain, dihormati dan disenangi karena keadaan diri kita, maka kita akan cendrung bersikap menghormati dan menerima diri kita. Sebaliknya bila orang lain selalu meremehkan kita, menyalahkan dan menolak keberadaan kita, maka kita akan cendrung tidak menyenangi diri kita. Pentingnya persepsi dan konsepsi terhadap orang lain dalam komunikasi kita, dapat difahami dengan banyak kajian yang memfokuskan pada aspek ini. Persepsi dan konsepsi terhadap orang lain itu sesungguhnya mempunyai pengaruh yang besar dalam komunikasi yang kita bangun, karena itulah munculnya berbagai istilah untuk kelompok ini. George Herbert Mead (1934) menyebutnya sebagai significant others atau orang lain yang sangat penting. Atau apa yang disebut oleh Richard Dewey \& W.J. Humber (1966) sebagai affectif others atau orang lain yang dengan mereka kita mempunyai ikatan emosional (lihat dalam Jalaluddin Rakhmat, 2004: 101-102).
Komunikasi yang kita bangun terhadap orang lain sangat bergantung pada `apa dan bagaimana` orang dalam persepsi dan konsepsi kita. Karena itu, menurut Jalaluddin Rakhmat (2004) kita multak harus berusaha meningkatkan kualitas/ketepatan dalam memberikan persepsi dan konsepsi terhadap orang lain dalam berkomunikasi.

Sebagai satu aspek penting dalam komunikasi, mengenal diri dan memberikan deskripsi yang dianggap mampu mewakili dalam proses komunikasi sesungguhnya bukanlah perkara mudah. Hal itu disebabkan ada banyak faktor yang terlibat dalam pengenalan diri, diantaranya dan paling utama adalah sikap diri yang cendrung tertutup dan dia bersedia untuk bercermin dengan orang lain yang berbeda. Jika mengacu pada teori pengenalan diri yang disebut windows teory (teori Jendela Jauhari) dalam psikologi komunikasi, maka kita akan menemukan empat bagian dalam diri kita yang harus disadari. Pertama, ada wilayah dalam diri kita yang bersifat terbuka (open self), dimana kita dan orang lain dapat mengenal tentang diri individu. Kedua, ada wilayah yang sifatnya tersembunyi (hidden self), yang orang lain tidak kenal pribadi kita, meskipun kita mengetahuinya. Ketiga, ada wilayah yang buta (blind self), dimana kita tidak menyadari tentang diri kita, tetapi orang lain melihatnya. Dan keempat, ada wilayah yang bersifat gelap 
dan tidak diketahui sama sekali (unknow self), dimana kita dan orang lain pun tidak mengenal karakter terdalam pada diri individu.

Berikut teori jendela Jauhari (Windows Teory) ditampilkan dalam bentuk gambar.

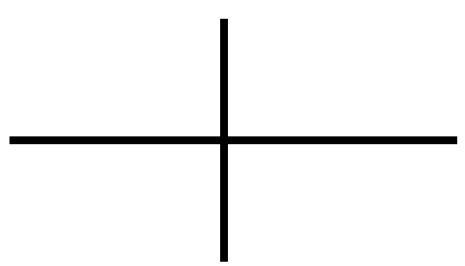

Sumber: Psikologi Komunikasi,Jalaluddin Rakhmat (2004: 108).

Bagian manapun dalam diri kita, kemauan dan kemampuan membuka diri dalam bentuk membuat deskripsi diri, untuk kemudian membuka bagi orang lain untuk mengenalnya adalah kata kunci dalam melebarkan wilayah open self dan mengecilkan wilayah hidden dan blind self. Sebab pada prinsipnya, keempat bagian (jendela diri dalam windows teory) itu tidak pernah sama besarnya. la akan senantiasa tarik menarik. Untuk melihat proses ini, berikut analisis deskripsi diri mahasiswa ditampilkan.

a. Sifat diri dalam Komunikasi

"Saya...orang mudah akrab, tetapi tidak mudah bergaul karena sifat pemalu yang besar.., enggan memulai komunikasi. Saya ... keras kepala, bertahan dengan prinsip dan tidak raguragu.."(agt)."Saya .. orang yang santai, disiplin dengan waktu, ramah pada semua orang" (dh)"Saya .. orang yang selalu berusaha ada di setiap teman membutuhkan bantuan, agar saya ... bermanfaat bagi orang lain. ...saya orang yang keras kepala..saya tidak suka meminta bantuan dari orang lain.." (Rt)

b. Kelebihan dan Kekurangan diri dalam Komunikasi

"Sifat baik dalam diriku ... anak yang selalu tersenyum dan bersemangat dalam segala hal, khususnya dalam menghafalkan Qur'an. Sifat burukku. terkadang tidak bisa mengontrol emosiku, lepas kendali, aku mencoba untuk menutupi sifat burukku tersebut" (Irw)

"Kelebihanku tidak pernah lupa untuk..Membaca ayat suci Al-Quran. Kekuranganku egois, keras kepala, mudah tersinggung, suka mengulurulur waktu" (Sa)

c. Hal yang disukai dan tidak disukai dalam komunikasi

"Hal yang paling disukai. Seseorang menyapa dengan ramah dan berbicara secara dewasa, menyapa dengan bahasa keakraban, tidak menjatuhkan satu sama lain. Hal yang paling saya benci. Seseorang bersikap acuh dan arogan, tidak bertanggung jawab dan mudah tersinggung" (Dd)

"Hal yang saya sukai. Menonton, baca komik dan novel, jalan-jalan, kuliner, sleeping. Saya tidak suka sifat yang manja dengan orang lain, Tidak suka dibohongi, tidak suka ada rahasia-rahasiaan, tidak suka 
diganggu pada saat saya tidur, Tidak suka menunggu..." (Mtr)

d. Kemampuan Komunikasi dan Pilihan Bahasa dalam Komunikasi

"Sehari-hari berkomunikasi menggunakan bahasa Melayu, karena ayahku keturunan Melayu. Aku bisa berbicara dengan nada keras, tegas jika situasi harus demikian. Aku juga bisa bicara dalam nada yang lembut sesuai konteksnya..." (Agt)

"Dalam pergaulan sehari-hari menggunakan bahasa Indonesia, dan kadang menggunakan bahasa daerah. Namun lebih mengutamakan perasaan orang lain. Apalagi jikalau lawan bicara saya adalah lebih tua, maka saya akan berhati-hati dalam berbicara" (Dh)

Berdasarkan kutipan deskripsi diri di atas, dapat kita fahami bahwa mahasiswa KPI telah mau berusaha dan mampu mengenalkan diri dan membuka diri untuk dikenal oleh orang lain. Meskipun deskripsi tersebut adalah sebuah latihan tugas kuliah "mencari teman antarbudaya", akan tetapi kemauan dan upaya tersebut menunjukkan adanya keterbukaan yang menjadi prasyarat membangun komunikasi yang baik dan efektif antarbudaya. Sebab semakin kita mampu mengenal diri (dengan segala potensi dan kelemahannya), maka akan semakin baik kita mengorganisasi diri dalam komunikasi, apalagi konteks antarbudaya.

Dengan memperhatikan bagaimana seseorang memberikan deskripsi tentang diri (konsepsi diri), sesungguhnya dapat dikenal beberapa tipe komunikasi yang cendrung ditampilkan. Dalam konteks ini menurut Jalaluddin Rakhmat (2004: 104110), sedikitnya ada empat tipe komunikasi yang diakibatkan oleh pengaruh konsepsi diri, yakni: Nubuat yang dipenuhi sendiri, membuka diri, percaya diri (self confidence), dan selektifitas.

Tipe Nubuat yang dipenuhi sendiri bermakna bahwa setiap orang akan bertingkah laku sesuai dengan konsep diri, termasuk dalam berkomunikasi. Karena itu kesuksesan sebuah komunikasi sangat bergantung pada kualitas/ketepatan mengenai konsep diri. Tipe membuka diri lebih dimaksudkan bahwa untuk meningkatkan pemahaman tentang diri, maka mutlak kita perlu memperbanyak komunikasi dengan orang lain. Realisasi tipe ini adalah sebagaimana dalam teori Jendela Jauhari (windows teory). Sedangkan tipe percaya diri menyakini bahwa potensi komunikasi akan mungkin didapatkan bagi orang yang memiliki tingkat kepercayaan diri yang baik. Sebaliknya, tidak percaya diri dalam komunikasi bukan saja bisa mengacaukan sebuah komunikasi, melainkan diawali dari sebuah konsep diri yang terlalu negatif. Brooks \& Emmert (1976) menyebutkan empat tanda konsep diri yang negatif itu, yakni peka terhadap kritik, responsif terhadap pujian, merasa tidak disenangi orang lain, dan pesimis terhadap kompetisi/peluang. Sedangkan 
tipe selektifitas adalah satu karakter komunikasi yang cendrung memperhatikan atau mengutamakan bagian-bagian tertentu secara selektif sesuai dengan konsep diri. Menurut Anita Taylor et.al (1977), konsep diri akan menyebabkan terpaan selektif (selective exposure), persepsi selektif (selective perception), dan ingatan selektif (selective attention).

Berdasarkan deskripsi diri mahasiswa (sebagaimana di atas) menunjukkan bahwa wujudnya ke empatempat tipe konsepsi diri. Dan dengan tipe inilah sesungguhnya menggambarkan bagaimana kecendrungan komunikasi antarbudaya yang dimiliki oleh masingmasing individu mahasiswa.

\section{Penutup}

Diri dan Orang Lain (self and the others) merupakan unsur penting dalam setiap komunikasi. Karena itu pemahaman yang baik terhadap diri dan orang lain akan sangat menentukan keberhasilan sebuah komunikasi. Dalam konteks komunikasi budaya, pemahaman terhadap diri dikenal dengan persepsi diri (self perception), yang akan memberikan sebuah gambaran utuh terhadap diri sendiri atau dikenal dengan istilah konsepsi diri (self conception), dimana setiap komunikasi senantiasa akan berlangsung mengikuti persepsi dan konsepsi diri tersebut.
Begitupun pemahaman terhadap orang lain atau persepsi terhadap orang lain (perception to the others) akan memberikan sebuah gambaran utuh mengenai orang tersebut atau konsepsi tentang orang lain (conception to the others), dimana setiap kita cendrung akan berkomunikasi dengan orang lain mengikuti apa yang kita gambarkan tentang orang tersebut. Karena itu, persepsi dan konsepsi diri sama pentingnya dengan persepsi dan konsepsi terhadap orang lain dalam komunikasi.

Beberapa hal yang penting dipahami dalam persepsi dan konsepsi diri, bahwa pemahaman tentang diri pribadi ini berkembang sejalan dengan perubahan yang terjadi dalam hidup kita. Kita tidak terlahir dengan pemahaman akan siapa diri kita, tetapi prilaku kita selama ini memainkan peranan penting bagaimana kita membangun pemahaman diri pribadi ini.

Persepsi pada akhirnya akan membentuk konsepsi tertentu terhadap apa yang dipersepsi. Karena itu persepsi dan konsepsi senantiasa pengaruh mempengaruhi. Persepsi yang salah akan membuat kelirunya konsepsi. Sebaliknya konsepsi yang salah juga akan membuat persepsi yang tidak benar. Jika digambarkan dalam bagan, maka persepsi dan konsepsi bagaikan lingkaran komunikasi ayam dan telur ayam, yang 
tidak pernah tau mana yang lebih dahulu keduanya.

Dengan kata lain, persepsi dan konsepsi terhadap diri akan menentukan pola dan bentuk komunikasi yang akan dilakukan. Ketika persepsi dan konsepsi terhadap diri baik dan benar, maka komunikasi yang dilangsungkan akan mungkin berjalan dengan baik, positif, penuh percaya diri dan maksimal. Sebaliknya jika persepsi dan konsepsi diri kurang baik dan keliru, maka komunikasi yang terbangun akan bersifat tidak maksimal dan kurang percaya diri.

Deskripsi diri (persepsi dan konsepsi diri) yang dilakukan oleh mahasiswa Komunikasi Penyiaran Islam Angkatan 2011/2012 dalam kerangka mengenal teman antrabudaya memberikan beberapa pemahaman tentang komunikasi antarbudaya; Pertama, dalam bentuk apapun, setiap kita akan memulai sebuah komunikasi dengan senantiasa mengikuti apa yang kita gambarkan tentang diri (persepsi diri dan konsepsi diri) dan orang lain (persepsi dan konsepsi terhadap orang lain), sebagaimana deskripsi yang diberikan oleh mahasiswa dalam Tabel C.1 dan Tabel C.2.

Kedua, apapun bentuknya, pengenalan diri (persepsi dan konsepsi diri) dan orang lain (persepsi dan konsepsi terhadap orang lain) akan mamandu setiap orang dalam membangun komunikasi sosialnya, apalagi dalam konteks komunikasi antarbudaya. Dengan kata lain, deskripsi diri dan orang lain yang diberikan oleh mahasiswa (sebagaimana dalam Tabel C.1 dan Tebel C.2 memberikan ciri komunikasi yang cendrung akan dilakukan terhadap teman antarbudaya.

Ketiga, berdasarkan persepsi dan konsepsi terhadap diri (sebagaimana data pada Tabel C. 1 memberikan identitas mengenai tipe komunikasi antarbudaya yang dapat dibangun dalam konteks pertemanan antarbudaya. Diantara identitas (tipe) komunikasi tersebut adalah selektifitas, membuka diri dan nubuat (untuk sifat diri); nubuat dan percaya diri (untuk kelebihan dan kekurangan diri); membuka diri, selektifitas dan nubuat (untuk hal yang disukai dan tidak disukai); serta membuka diri, selektifitas dan nubuat (untuk kemampuan komunikasi dan pilihan bahasa).

Keempat, berdasarkan persepsi dan konsepsi terhadap orang lain (sebagaimana data pada Tabel C.2 memberikan identitas/tipe komunikasi antarbudaya yang dapat dibangun dalam konteks pertemanan antarbudaya. Diantara identitas tersebut adalah; membuka diri, percaya diri dan selektifitas (untuk sifat baik dan tidak baik pada teman); selektifitas, nubuat dan membuka diri (untuk hal yang paling disukai dan tidak disukai teman). 
Kelima, dari aspek alasan memilih teman (sebagaimana deskripsi data pada Tabel C.3) memberikan pemahaman mengenai peringkat komunikasi yang dapat dibangun oleh mahasiswa dalam konteks pertemanan antarbudaya. Peringkat (tipe) komunikasi tersebut meliputi; jarak pribadi (Hall, 1963) dan tingkat keakraban (Altman \& Taylor, 1973), serta jarak sosial (Hall, 1963) dan tingkat keterlibatan (Altman \& Taylor, 1973)

Karena itu, jika mengikuti pandangan Porter dan Samovar, dapat disimpulkan bahwa deskripsi diri (persepsi dan konsepsi diri) dan deskripsi teman (persepsi dan konsepsi terhadap orang lain) yang dilakukan oleh mahasiswa menunjukkan satu kesatuan makna antara pengalaman (eksperience), pengetahuan (reference) dan pemahaman komunikasi mereka yang berwujud kepada beberapa klasifikasi tipe komunikasi sebagaimana di atas. Proses ini sejalan dengan pernyataan kedua pakar komunikasi budaya tersebut yang menyatakan bahwa "kemiripan budaya dalam persepsi memungkinkan pemberian makna yang mirip pula terhadap suatu objek sosial atau suatu peristiwa", termasuklah terhadap diri dan orang lain.

\section{E. Daftar Pustaka}

Alo Liliweri. 2003. Dasar-dasar Komunikasi Antarbudaya. Bandung: Rosda Karya

Deddy Mulyana. 2002. IImu Komunikai: Suatu Pengantar. Bandung: Rosda Karya

DeddyMulyana dan Jalaluddin Rakhmat. 2001. Komunikasi Antarbudaya. Bandung: Rosda Karya.

Devito, Joseph. 1997. Komunikasi Antaramanusia, Profesional Books Jakarta

Ibrahim. 2010. Hidup dan Komunikasi. Pontianak: STAIN Pontianak Press

Ibrahim. 2009. Komunikasi Antarbudaya. Pontianak: STAIN Press.

Ibrahim. 2015. "Makna" dalam Komunikasi. Artikel dalam Jurnal Al-Hikmah, Vol. IX No. 1 (Juni 2015), h. 18-29.

Jalaluddin Rakhmat. 2004. Psikologi Komunikasi. Edisi Revisi. Bandung: Rosda Karya.

Roger\& Stienfatt. 1986. Intercultural Communication.

WavelanPress; Witted State of Amerika.

Sendjaja, S. Djuarsa, P.D dkk. 1998. Teori Komunikasi. Modul IImu Komunikasi Universtas Terbuka, hal. 1-9

Shamsul Amri Baharudin (ed.), 2007. Modul Hubungan Etnik. Kuala lumpur: Kementerian Pengajian Tinggi Malaysia. 